\title{
Disease-free survival in patients with non-metastatic breast cancer
}

\author{
Roberta Wolp Diniz ${ }^{1 *}$, Maximiliano Ribeiro Guerra ${ }^{2}$, Jane Rocha Duarte Cintra ${ }^{3}$, Vívian Assis Fayer ${ }^{4}$, \\ Maria Teresa Bustamante Teixeira ${ }^{5}$

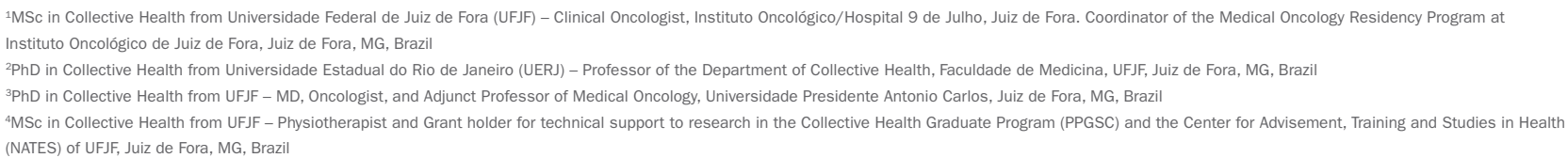

Study conducted as part of a dissertation in the Collective Health Graduate Program, Universidade Federal de Juiz de Fora (UFJF), Juiz de Fora, MG, Brazil

Article received: 3/18/2015 Accepted for publication: 5/25/2015

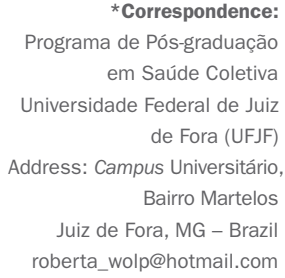

\section{SUMmARY}

Introduction: Breast cancer is the second most common malignancy in the world and the one with highest incidence in the female population; it is also a major cause of death from cancer among women.

Objective: To analyze the disease-free survival (DFS) at 5 years and prognostic factors in women with non-metastatic invasive breast cancer treated at a referral center for cancer care located in a medium-sized city in the Southeast of Brazil.

Method: Patients diagnosed with the disease between 2003 and 2005 and identified through the institution's cancer hospital records were analyzed. The follow-up of cases was carried out through hospital records, and complemented by search in the database of the Mortality Information System (SIM) as well as telephone contact. The variables analyzed were distributed in the following blocks: socio-demographic data, tumor-related characteristics, and treatment-related characteristics. Survival functions were calculated using the Kaplan-Meier method and the prognostic factors were analyzed based on Cox proportional hazard model.

Results: The study showed a DFS at 5 years of $72 \%$ (95CI 67.6-75.9). The main variables independently associated with DFS were lymph node involvement, use of hormone therapy, and education level.

Conclusion: This study reinforces the importance of early diagnosis for DFS, pointing to the role of social aspects in this regard. The relevance of this research in the country is also highlighted, given the scarcity of studies on DFS in the Brazilian population.

Keywords: breast neoplasm's, survival analysis, survival.

\section{INTRODUCTION}

Breast cancer is the second most frequent cancer in the world and the cancer with the highest incidence in the female population, ${ }^{1-3}$ both in more developed and less developed regions. ${ }^{3}$ However, breast cancer mortality has been declining over the last few decades in high-income countries such as the USA, United Kingdom, France and Australia. ${ }^{4}$

For Brazil, the estimate is 57,120 new cases of breast cancer for the year 2014, making it the tumor with the largest incidence in the Southeast, South, Midwest and Northeast regions, and the second most incident in the North, where it is preceded by cervical cancer. ${ }^{5}$ As of the mid-1990s, a reduction began to be observed in breast cancer deaths in women residing in the capitals of the Southeast and South of Brazil. ${ }^{4}$

Breast cancer is a heterogeneous pathology and the course of the disease depends on several factors, which may be inherent in the tumor, the patient and socioeconomic conditions. Some of the factors that can influence disease progression include: early diagnosis, staging, histological and biological tumor characteristics, age, ethnic and social factors, and more. ${ }^{6-8}$ Early diagnosis associated with treatment could reduce the mortality of the disease..$^{8-12}$ 
Disease-free survival (DFS) is defined as the time between the beginning of the treatment and disease progression or death from any cause. ${ }^{13-15}$ Factors related to a shorter DFS include tumors larger than $2 \mathrm{~cm}$, the presence of lymph node involvement and more advanced stages of the disease. ${ }^{6,16,17}$

Studies have shown that the proposed therapeutic modalities for breast cancer may also interfere with DFS in a significant manner. The use of adjuvant chemotherapy for breast cancer patients has enabled greater control of the disease and, consequently, an increase in DFS. ${ }^{13,18,19}$ For women with hormone-receptor-positive breast cancer, the use of adjuvant endocrine therapy is related to an increase in DFS. ${ }^{20}$ Tumors with overexpression of HER2 confer upon patients a worse prognosis, with decreased DFS, and the use of specific therapy in these cases makes it possible to reduce the risk of recurrence in almost $50 \% .{ }^{21}$ According to a meta-analysis performed by the Early Breast Trialists' Collaborative Group, ${ }^{22}$ adjuvant radiation therapy lowers the risk of locoregional or systemic recurrence over 10 years from 35 to $19.3 \%$.

Analysis of DFS and associated factors enables a better understanding of the profile of the patients and of recurrence-related characteristics, providing a basis for more suitable therapeutic guidance. It should be noted, however, that studies in the national literature conducted to investigate the recurrence of the disease and its related factors in the Brazilian context are very scarce.

The present study addressed the analysis of diseasefree survival in patients with invasive, non-metastatic breast cancer.

\section{Method}

The study population was composed of a retrospective, hospital-based cohort, which included women diagnosed with breast cancer between 2003 and 2005, treated at the cancer care center in the city of Juiz de Fora, Minas Gerais.

The recruitment of 563 women diagnosed with breast cancer was conducted after searching the institution's hospital database for cancer records. According to the established selection criteria, the population of this study only included patients staged I, II or III upon diagnosis (nonmetastatic) who had received any kind of treatment (neoadjuvant or adjuvant), which totaled 459 cases. The collection of data from the medical records was conducted with a standardized instrument by trained personnel and supervised by specialists in Oncology, aimed at improving the interpretation of the information present in the records.

To analyze disease-free survival at 5 years, the start date of the supplementary treatment was considered as the beginning of the survival time. The monitoring period of the cases was 60 months after the beginning of supplementary treatment for each case, covering 5 years after the start date of adjuvant therapy of the last patient included in the study.

Failure was considered as locoregional relapse or distant metastasis (date of the clinical diagnosis or imaging examination) or death by any cause.

Patients that remained without signs of recurrence by the end date of monitoring and those with loss of monitoring were excluded, considering the date referring to the last follow-up registered in the medical record for the analysis.

In order to improve the information, the participants in the study were contacted by the hospital cancer registry via telephone calls, collecting data relating mainly to the socio-demographic characteristics and verification of the clinical condition of the patient.

For cases whose information was not retrieved, we returned to the medical records and subsequently contacted the mastologist in charge. A search was then conducted on the regional Mortality Information System (SIM) for all cases. For patients who still have a loss of monitoring, a consultation was made on the Taxpayer Registry (CPF) for verification of information relating to whether the patient was still registered as living.

The independent variables analyzed were distributed into the following blocks: 1 . socio-demographic: age at diagnosis (categorized as: $\leq 39,40-49,50-69$ and $\geq 70$ ); menopausal status (pre-menopausal: $\leq 50$ years; post-menopausal: >50 years); skin color (white or non-white); level of education (low, medium, and high); family history of breast cancer; presence of private health plan and nature of the Oncology service (public: program in partnership with the SUS or private), 2. tumor-related: tumor size (categorized as $\leq 2.0 \mathrm{~cm}$ and $>2.0 \mathrm{~cm})$; impairment of lymph nodes $(0$; $1-3$; $4-9$ and $\geq 10$ ); staging based on the TNM Classification proposed by the Union for International Cancer Control (UICC) (I, II and III); tumor subtypes based on immunohistochemical classification (luminal HER2-negative, luminal HER2-positive, overexpressed HER2, triple negative and unknown subtype); tumor grade; and neurovascular invasion, 3. treatment-related: type of surgery (conservative or radical); use of radiotherapy, chemotherapy and hormone therapy; groups of complementary treatment performed (exclusive radiotherapy; exclusive chemotherapy; exclusive hormone therapy; chemotherapy and radiotherapy; chemotherapy, radiotherapy and hormone therapy; radiotherapy and hormone therapy; chemotherapy and hormone therapy) and the time interval in weeks between surgery and adjuvant chemotherapy ( $\leq 12$ weeks or $>12$ weeks). 
The differences observed in the distribution of the main study variables were assessed using $\chi 2$ test and, when necessary, Fisher's exact test, with statistical significance considered for those with a $\mathrm{p}$-value $<0.05$.

The probabilities of disease-free survival were calculated according to the method proposed by Kaplan-Meier, grouping the patients according to the variables selected for the study. Log-rank test was used for comparison of the survival functions for each variable.

For the assessment of prognostic variables, we used Cox regression model for proportional hazards, calculating the hazard ratio (HR) and confidence intervals of $95 \%{ }^{23}$ The selection of variables was carried out using the significance obtained from the univariate Cox model, considering the significance level of $\mathrm{p} \leq 0.2$, and relevance in the literature. The variables that met the criteria previously described were included in the analysis and selected through the process of "backward elimination." The significance of the parameters of the reduced models and the final model was verified using likelihood ratio test, and proportionality of the Cox models was verified using Schoenfeld Residuals. ${ }^{24}$

EPI Info 2012 software was used for entry and descriptive analysis of the data, as well as Stata, version 10.0, for disease-free survival analysis.

\section{Results}

The average age of the population studied was 57.4 years, with most women (47\%) in the age group with the highest incidence of the disease, i.e. from 50 to 69 years, and $7.8 \%$ aged less than 40 years.

Disease recurrence was verified in 129 women. $17.8 \%$ of these patients showed locoregional recurrence, $54.3 \%$ progressed with distant metastases and $27.9 \%$ died. All the patients who died in the period considered in this study had breast neoplasm as cause of death.

Table 1 shows the distribution of the variables that showed a significant difference with regard to recurrence of the disease.

Disease-free survival (DFS) at 5 years for the population studied was $72 \%$ (95CI 67.6-75.9).

With regard to the socio-demographic variables, the survival functions presented the highest percentages for white women $(74.4 \%)$ and for those with high and average level of education (85.0 and $70.9 \%$, respectively). Meanwhile, with regard to tumor-related variables, the best rates of DFS were those of women who had tumors $\leq 2 \mathrm{~cm}(82.2 \%)$, absence of lymph node involvement (81.9\%), grade 1 tumor $(79.2 \%)$ and those with HER2negative luminal tumors $(79.0 \%)$. With regard to treat- ment-related variables, the best rates of DFS were identified in women who were undergoing conservative surgery $(77.9 \%)$, those who did not receive chemotherapy $(83 \%)$, and those who underwent hormone therapy (79.4\%). The treatment group with best DFS rates was women who underwent hormone therapy associated with radiotherapy $(87.6 \%)$.

In the multivariate analysis, level of education (medium: $\mathrm{HR}=1.60$, 95CI 0.84-3.08; low: $\mathrm{HR}=1.84$, 95CI 0.963.52; unknown: $\mathrm{HR}=2.05$, 95CI 0.97-4.34), lymph node involvement $(\mathrm{HR}=2.35,95 \mathrm{CI} 1.61-3.42)$ and hormone therapy (HR=0.37, 95CI 0.26-0.53) appeared as independent prognostic factors, as shown in Table 2. Figure 1 displays the curves of DFS for the main variables maintained in the final model.

\section{Discussion}

The present study examined DFS at 5 years for 563 patients with non-metastatic breast cancer and demonstrated a result of $72 \%$ (95CI 67.6-75.9). DFS studies for breast cancer are still scarce in Brazil. In our review, we only identified the study by Crippa et al., which found a DFS rate of $56.1 \%$ in women younger than 35 years. ${ }^{25}$ In a retrospective study of 2,040 women conducted between 1990 and 1999 in Korea, DFS of $69.6 \%$ was found for patients under the age of 35 years and $81.3 \%$ for women over the age of 35 years. ${ }^{26}$ In our cohort, DFS for women under the age of 40 years was $58.7 \%$, though only with marginal statistical significance $(\mathrm{p}=0.08)$.

In the final Cox regression model for proportional hazards, the most important prognostic factors were: lymph node involvement, which was related to a 2.35 increase in the risk of recurrence of the disease and realization of hormone therapy which, on the other hand, was responsible for a $63 \%$ reduction in the risk of recurrence. An increased risk of recurrence was also noted as the level of education decreased, although with only marginal significance (middle education: $\mathrm{HR}=1.60 ; \mathrm{p}=0.1$ and low: $\mathrm{HR}=1.84 ; \mathrm{p}=0.07$ ).

The greatest risk of relapse associated with lymph node involvement in the study population is in accordance with the scientific literature. More advanced stages of breast neoplasm are related to shorter DFS and overall survival. ${ }^{11,27-29}$ A survey of women with stage III breast cancer subject to the same kind of treatment showed a difference in DFS at 5 years between stage IIIA (84\%) and IIIB (33\%) patients. ${ }^{30}$ In a study that compiled data from the EUROCARE and SEER trials, the risk of death was shown to increase alongside staging (T2-3NOM0: risk of 4.87; T1-3NM0: risk of 10.44; T4M0: risk of 17.22; all in relation to T1NOM0). ${ }^{31}$ 
TABLE 1 Distribution of the variables by disease recurrence status, Juiz de Fora, 2003-2005.

\begin{tabular}{|c|c|c|c|c|c|}
\hline \multirow{3}{*}{ Variables } & \multicolumn{5}{|c|}{ Disease recurrence } \\
\hline & \multicolumn{2}{|c|}{ Present $(\mathrm{N}=129)$} & \multicolumn{2}{|c|}{ Absent $(N=330)$} & \multirow[t]{2}{*}{ p-value* } \\
\hline & $\mathbf{N}$ & $\%$ & $\mathbf{N}$ & $\%$ & \\
\hline Skin color\# & & & & & 0.004 \\
\hline White & 90 & 72.6 & 262 & 84.5 & \\
\hline Non white & 34 & 27.4 & 48 & 15.5 & \\
\hline Education & & & & & 0.03 \\
\hline Higher education & 12 & 9.3 & 68 & 20.6 & \\
\hline Middle education & 45 & 34.9 & 110 & 33.3 & \\
\hline Low education & 53 & 41.1 & 112 & 33.9 & \\
\hline Unknown & 19 & 14.7 & 40 & 12.1 & \\
\hline Staging & & & & & $<0.001$ \\
\hline 1 & 15 & 11.6 & 111 & 33.6 & \\
\hline II & 49 & 38.0 & 149 & 45.2 & \\
\hline III & 65 & 50.4 & 70 & 21.2 & \\
\hline Tumor size\# & & & & & $<0.001$ \\
\hline$\leq 2 \mathrm{~cm}$ & 33 & 26.4 & 152 & 46.6 & \\
\hline$>2 \mathrm{~cm}$ & 92 & 73.6 & 174 & 53.4 & \\
\hline Lymph node involvement\# & & & & & $<0.001$ \\
\hline No & 44 & 35.8 & 200 & 61.2 & \\
\hline Yes & 79 & 64.2 & 127 & 38.8 & \\
\hline Tumor grade & & & & & 0.03 \\
\hline 1 & 23 & 17.8 & 88 & 26.7 & \\
\hline 2 & 45 & 34.9 & 118 & 35.8 & \\
\hline 3 & 31 & 24.0 & 45 & 13.6 & \\
\hline Unknown & 30 & 23.3 & 79 & 23.9 & \\
\hline Immunohistochemical profile & & & & & $<0.001$ \\
\hline Unknown & 18 & 14.0 & 43 & 13.0 & \\
\hline Luminal HER2-negative & 54 & 41.9 & 204 & 61.8 & \\
\hline Luminal HER2-positive & 7 & 5.4 & 25 & 7.6 & \\
\hline Overexpressed HER2 & 15 & 11.6 & 10 & 3.0 & \\
\hline Triple negative & 35 & 27.1 & 48 & 14.5 & \\
\hline Type of surgery\# & & & & & 0.01 \\
\hline Conservative & 51 & 41.1 & 180 & 54.5 & \\
\hline Radical & 73 & 58.9 & 150 & 45.5 & \\
\hline Chemotherapy & & & & & $<0.001$ \\
\hline Use & 106 & 82.2 & 217 & 65.8 & \\
\hline Non-use & 23 & 17.8 & 113 & 34.2 & \\
\hline Hormone therapy & & & & & $<0.001$ \\
\hline Use & 67 & 51.9 & 260 & 78.8 & \\
\hline Non-use & 62 & 48.1 & 70 & 21.2 & \\
\hline
\end{tabular}

*Chi-squared test (or Fisher's exact test, wherever indicated); significant if $\mathrm{p}<0.05$; \#The sum is lower due to missing data on: skin color $-21(4.5 \%)$, tumor size $-8(1.7 \%)$; lymph node involvement $-9(2.0 \%)$; type of surgery $-5(1.1 \%)$. 
TABLE 2 Unadjusted and adjusted hazard ratios (HR) of the variables remaining in the final Cox model.

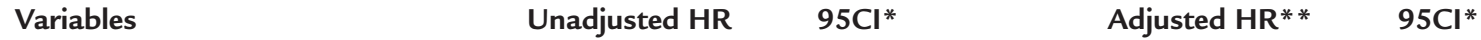

\section{Education}

\begin{tabular}{|c|c|c|c|c|}
\hline Higher & 1.00 & & 1.00 & \\
\hline Middle & 2.19 & $1.16-4.15$ & 1.60 & $0.84-3.08$ \\
\hline Low & 2.37 & $1.26-4.43$ & 1.84 & $0.96-3.52$ \\
\hline Unknown & 2.48 & $1.20-5.10$ & 2.05 & $0.97-4.34$ \\
\hline \multicolumn{5}{|c|}{ Lymph node involvement } \\
\hline Absent & 1.00 & & 1.00 & \\
\hline Present & 2.38 & $1.64-3.44$ & 2.35 & $1.61-3.42$ \\
\hline \multicolumn{5}{|c|}{ Hormone therapy } \\
\hline Not performed & 1.00 & & 1.00 & \\
\hline Performed & 0.35 & $0.25-0.49$ & 0.37 & $0.26-0.53$ \\
\hline
\end{tabular}

*95CI 95\% confidence interval; **Adjusted by age at diagnosis (continuous format), in addition to the three variables in the Table.

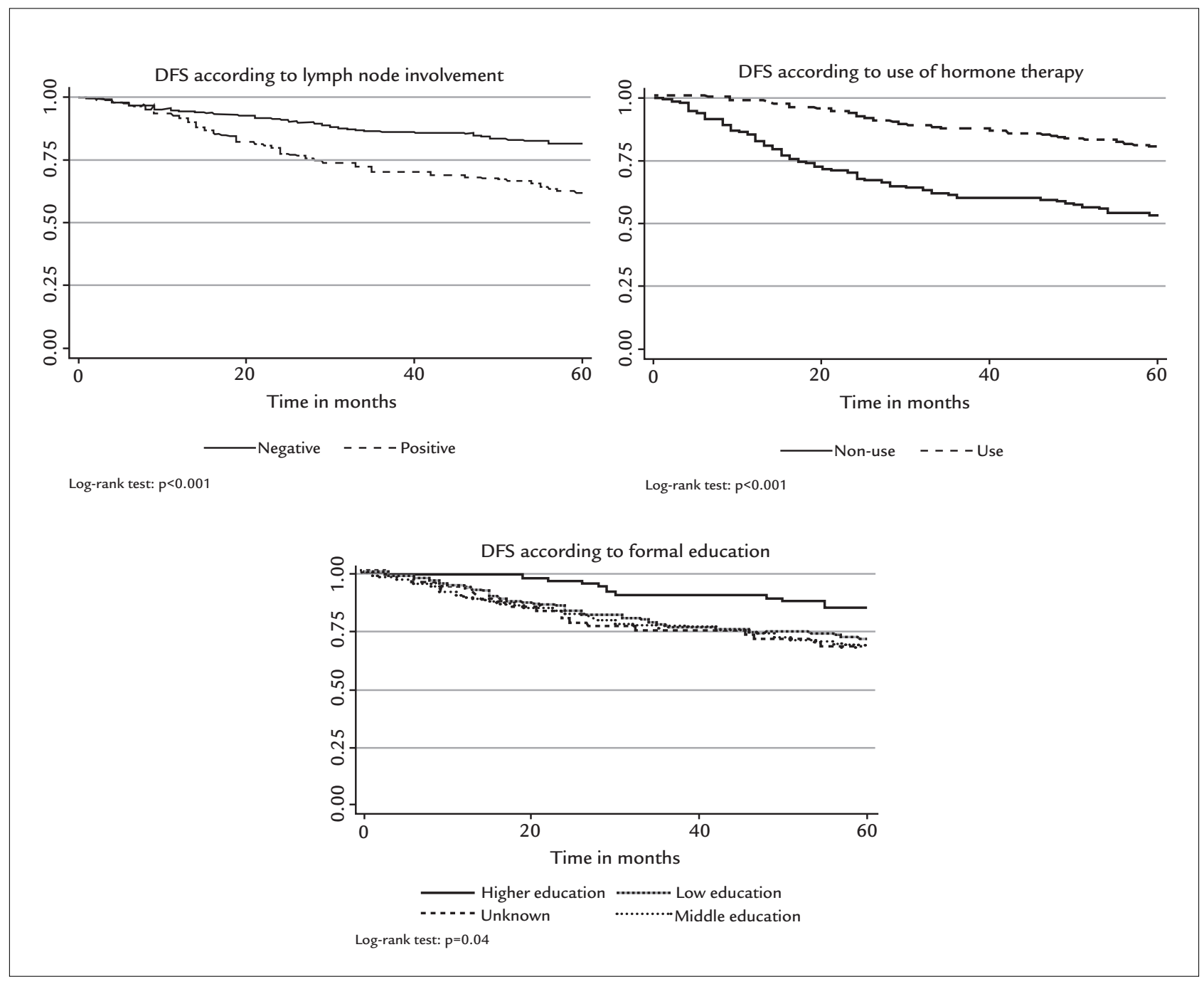

FIGURE 1 Curves of disease-free survival (DFS) for the main variables maintained in the final model. 
Allemani et al. noted relative survival estimates of $89 \%$ for patients with tumors confined to the breast and $62 \%$ for tumors with lymph node involvement. ${ }^{32} \mathrm{Kim}$ et al. showed DFS of 113 months for patients with breast cancer with no lymph node involvement and 84 months for those who presented lymph node metastases. ${ }^{33}$

Adjuvant hormone therapy with tamoxifen was responsible for a reduction in the risk of recurrence of $41 \%$ and in the risk of death from breast cancer of $34 \%$ in women in a study by the Early Breast Cancer Trialists' Collaborative Group - EBCTCG. ${ }^{18}$ A meta-analysis involving post-menopausal patients with positive estrogen receptors showed a superiority of aromatase inhibitors over tamoxifen, with a relative reduction of $23 \%$ in the risk of recurrence for the first drug, but without a significant difference in breast cancer mortality or death by any other cause. ${ }^{34}$ For the patients evaluated in this study, the use of hormone therapy enabled a reduction of $63 \%$ in the risk of recurrence within 5 years in the adjusted DFS anal$y$ sis ( $p<0.001)$, even without identifying the type of medication used, which reinforces the importance of this therapeutic modality in breast cancer.

It is worth noting that the socioeconomic profile of the population in our study was unfavorable in terms of formal education, given that $35.9 \%$ presented a low level of education and $12.9 \%$, unknown schooling. Considering the population of Juiz de Fora older than 15 years, however, $12.6 \%$ had a low level of education and $8.7 \%$ unknown schooling. ${ }^{35}$ For patients with unknown schooling, $55.9 \%$ had tumors $>2 \mathrm{~cm}$ and the majority featured more advanced stages of the disease (stage II: $40.7 \%$, and stage III: $30.5 \%$ - data not presented). In the multivariate analysis, low level of education was associated with increased risk of disease recurrence, although with only marginal significance. Such findings reinforce the possibility of a relationship between a low level of education and low access to specialized services, with a consequent delay in diagnosis and impaired therapeutic approach.

Certain limitations should be considered in the interpretation of the results, one of which is the fact that this study was conducted using secondary data, which may have affected the quality and availability of the information analyzed. It should also be taken into account that the differences observed in the comparison of DFS at 5 years in this research and that obtained in other studies included as reference could be influenced by differences in the populations studied, the periods selected for study, eligibility criteria, the methods adopted for analysis, and also the chemotherapeutic schemes adopted, which might have been different.

\section{Conclusion}

Breast cancer is a global public health problem and studies that help to understand the disease, its progression and associated factors are extremely important.

The analysis of DSF at 5 years performed in this study enabled us to have a better understanding of the profile of patients treated at the oncology service, the natural history of the disease and the factors involved in prognosis within a national context.

The expansion of screening aimed at early diagnosis of breast cancer represents an important strategy to achieve better DFS and overall survival, associated with ensuring access by women to suitable treatment. These conditions are particularly important in the population examined. Knowledge of the main characteristics and the factors associated with disease progression strengthens the need for new studies at Brazilian cancer treatment centers in order to obtain control of breast cancer in the country.

\section{Resumo}

Sobrevida livre de doença em pacientes com câncer de mama não metastático

Introdução: o câncer de mama é o segundo mais frequente no mundo e o de maior incidência na população feminina, além de ser uma das principais causas de óbito por câncer em mulheres.

Objetivo: analisar a sobrevida livre de doença (SLD) em 5 anos e fatores prognósticos em mulheres com câncer de mama invasivo não metastático tratadas em centro de referência em assistência oncológica de cidade de porte médio da região Sudeste do Brasil.

Método: foram analisadas as pacientes diagnosticadas com a doença entre 2003 e 2005, identificadas por meio do registro hospitalar de câncer da instituição. O seguimento dos casos foi realizado por meio de consulta aos prontuários, complementada por busca no banco do Sistema de Informação sobre Mortalidade (SIM) e contato telefônico. As variáveis analisadas foram distribuídas nos seguintes blocos: sociodemográficas, características relativas ao tumor e características relativas ao tratamento. As funções de sobrevida foram calculadas por meio do método de Kaplan-Meier. O modelo de riscos proporcionais de Cox foi utilizado para avaliação dos fatores prognósticos.

Resultados: o estudo mostrou uma SLD em 5 anos de $72 \%$ (IC95\%: 67,6-75,9). As principais variáveis associadas à SLD, de forma independente, foram o comprometimento linfonodal, a realização de hormonioterapia e o nível de escolaridade. 
Conclusão: este estudo reforça a importância do diagnóstico precoce para a SLD, apontando para o papel de aspectos sociais. Destaca-se a relevância desta pesquisa haja vista a escassez de estudos a respeito de SLD na população brasileira.

Palavras-chave: neoplasias da mama, análise de sobrevida, sobrevida.

\section{References}

1. Siegel R, Naishadham D, Jemal A. Cancer Statistics, 2012. CA Cancer J Clin. 2012; 62(1):10-29.

2. Bray F, Ren JS, Masuyer E, Ferlay J. Global estimates of cancer prevalence for 27 sites in the adult population in 2008. Int J Cancer. 2013; 132(5): $1133-45$.

3. International Agency for Research on Cancer. Globocan 2012: Estimated cancer incidence, mortality and prevalence worldwide in 2012. Available from: http://globocan.iarc.fr/Pages/fact_sheets_cancer.aspx.

4. Girianelli VR, Gamarra CJ, Azevedo e Silva G. Os grandes contrastes na mortalidade por câncer do colo uterino e de mama no Brasil. Rev Saude Publ. 2014; 48(3):459-67.

5. Instituto Nacional de Câncer José Alencar Gomes da Silva. Coordenação Geral de Ações Estratégicas. Coordenação de Prevenção e Vigilância. Estimativa 2014: incidência de câncer no Brasil. 1.ed. Rio de Janeiro: Inca; 2014. $124 \mathrm{p}$.

6. Abreu E, Koifman S. Fatores prognósticos no câncer da mama feminina. Rev Bras Canc. 2002; 48(1):113-31.

7. Buitrago F, Uemura G, Sena MCF. Fatores prognósticos em câncer de mama. Com Cien Saude. 2011; 22(Suppl 1):s69-s82.

8. Martindale S, Singh A, Wang H, Steinberg A, Homsi A, Zhang H, et al. Racial disparities in survival and age-related outcome in postsurgery breast cancer patients in a New York City community hospital. ISRN Oncol. 2014; 2014:1-9.

9. Berry DA, Cronin KA, Plevritis SK, Fryback DG, Clarke L, Zelen M, et al. Effect of screening and adjuvant therapy on mortality from breast cancer. N Engl J Med. 2005; 353(17):1784-92.

10. Soerjomataram I, Louwman MW, Ribot JG, Roukema JA, Coebergh JW. An overview of prognostic factors for long-term survivors of breast cancer. Breast Cancer Res Treat. 2008; 107(3):309-30.

11. Guerra MR, Mendonça GAS, Teixeira MTB, Cintra JRD, Carvalho LM, Magalhães LMPV. Sobrevida de cinco anos e fatores prognósticos em coorte de pacientes com câncer de mama assistidas em Juiz de Fora, Minas Gerais, Brasil. Cad Saude Pública. 2009; 25(11):2455-66.

12. Jemal A, Bray F, Center MM, Ferlay J, Ward E, Forman D. Global Cancer Statistics. CA Cancer J Clin. 2011; 61(2):69-90.

13. Machado KK, Katz A, Buyse M, Saad ED. Sobrevida global e outros desfechos clínicos em câncer de mama: situação atual e controvérsias. Rev Assoc Med Bras. 2010; 56(5):493-516.

14. Saad ED, Katz A. Progression-free survival and time to progression as primary end points in advanced breast cancer: often used, sometimes loosely defined. Ann Oncol. 2009; 20(3):460-4.

15. Saad ED, Katz A, Hoff PM, Buyse M. Progression-free survival as surrogate and as true end point: insights from the breast and colorectal cancer literature. Ann Oncol. 2010; 21(1):7-12.

16. Fisher B, Slack NH, Bross ID. Cancer of the breast: size of neoplasm and prognosis. Cancer. 1969; 24(5):1071-80.
17. Lopes LA, Linhares JJ, Ferraro O, Lopes RGC, Bacarat FF. Valor prognóstico do grau histológico (GH), grau nuclear (GN) e índice mitótico (IM) para pacientes com carcinoma da mama estádios II e III com linfonodos axilares comprometidos. Rev Bras Canc. 2006; 52(3):245-51.

18. Early Breast Cancer Trialists' Collaborative Group. Effects of chemotherapy and hormonal therapy for early breast cancer on recurrence and 15-year survival: an overview of randomized trials. Lancet. 2005; 365(9472):1687-1717.

19. De Laurentiis M, Cancello G, D'Agostino D, Giuliano M, Giordano A, Montagna E, et al. Taxane-based combinations as adjuvant chemotherapy of early breast cancer: a meta-analysis of randomized trials. J Clin Oncol. 2008; 26(1):44-53.

20. Doughty JC. A review of the BIG results: the Breast International Group 1-98 trial analyses. Breast. 2008; 17(Suppl 1):s9-s14.

21. Piccart-Gebhart MJ, Procter M, Leyland-Jones B, Goldhirsch A, Untch M, Smith, et al. Trastuzumab after adjuvant chemotherapy in HER2-positive breast cancer. N Engl J Med. 2005; 353(16):1659-72.

22. Early Breast Cancer Trialists' Collaborative Group, Darby S, McGale P, Correa C, Taylor C, Arriagada R, et al. Effect of radiotherapy after breastconserving surgery on 10-year recurrence and 15 -year breast cancer death: meta-analysis of individual patient data for 10,801 women in 17 randomised trials. Lancet. 2011;378(9804):1707-16.

23. Kleinbaum DG, Klein M. Survival analysis: a self-learning text. 2.ed. New York: Springer; 2005. 606p.

24. Cleves MA, Gould WW, Gutierrez RG. An introduction to survival analysis using Stata. College Station: Stata Press; 2002. 290p.

25. Crippa CG, d'Acampora AJ, Araújo EJ, Marasciulo AC, Hallal ALC, Gondin G. Câncer de mama em mulheres jovens: um estudo de probabilidade de sobrevida livre de doença. Rev Bras Mast. 2002; 12(4): 23-8.

26. Han W, Kim SW, Park IA, Kang D, Kim SW, Youn YK, et al. Young age: an independent risk factor for disease-free survival in women with operable breast cancer. BMC Cancer. 2004; 4:82.

27. Voogd AC, Nielsen M, Peterse JL, Blichert-Toft M, Bartelink H, Overgaard $\mathrm{M}$, et al. Differences in risk factors for local and distant recurrence after breast-conserving therapy or mastectomy for stage I and II breast cancer: pooled results of two large European randomized trials. J Clin Oncol Res. 2001; 19(6):1688-97.

28. Giordano SH, Buzdar AU, Smith TL, Kau SW, Yang Y, Hortobagyi GN. Is breast cancer survival improving? Cancer. 2004; 100(1):44-52.

29. Cintra JRD. Sobrevida de pacientes com câncer de mama submetidas à quimioterapia adjuvante nos serviços de oncologia em Juiz de Fora, Minas Gerais. [Dissertation]. Juiz de Fora: Faculdade de Medicina, Universidade Federal de Juiz de Fora; 2007.

30. Hortobagyi GN, Ames FC, Buzdar AU, Kau SW, McNeese MD, Paulus D, et al. Management of stage III primary breast cancer with primary chemotherapy, surgery, and radiation therapy. Cancer. 1988; 62(12):2507-16.

31. Sant M, Allemani C, Berrino F, Coleman MP, Aareleid T, Chaplain G, et al. Breast carcinoma survival in Europe and the United States. Cancer. 2004; 100(4):715-22.

32. Allemani C, Minicozzi P, Berrino F, Bastiaannet E, Gavin A, Galceran J, et al. Predictions of survival up to 10 years after diagnosis for European women with breast cancer in 2000-2002. Int J Cancer. 2013; 132(10): 2404-12.

33. Kim HS, Park I, Cho HJ, Gwak G, Yang K, Bae BN et al. Analysis of the potent prognostic factors in luminal-type breast cancer. J Breast Cancer. 2012; 15(4):401-6.

34. Dowsett M, Nielsen TO, A'Hern R, Bartlett J, Coombes RC, Cuzicket J, et al. Assessment of Ki67 in breast cancer: recommendations from the International Ki67 in Breast Cancer Working Group. J Natl Cancer Inst. 2011; 103(22):1656-64.

35. Brasil. Ministério da Saúde. Datasus. Informações de Saúde: demográficas e socioeconômicas. Escolaridade da população de 15 anos ou mais, Minas Gerais. Available from: http://tabnet.datasus.gov.br/cgi/tabcgi.exe?ibge/ censo/cnv/escaMG.def. 